\title{
The Relationship between Firm Performance as indicated by Financial Performance and Equity Market Premium. A Case of Safaricom Kenya
}

\author{
Constance Nganga ${ }^{1}$ Prof. Namusonge G. S. ${ }^{2}$ Oluoch J. Oluoch ${ }^{3}$, \\ Dr. Musiega Douglas ${ }^{4}$ \\ ${ }^{I}$ Masters Student Jomo Kenyatta University of Agriculture and Technology, Kakamega campus \\ ${ }^{2}$ Lecturer Jomo Kenyatta University of Agriculture and Technology, Kakamega campus \\ ${ }^{3}$ Lecturer Jomo Kenyatta University of Agriculture and Technology, Juja campus \\ ${ }^{4}$ Director Jomo Kenyatta University of Agriculture and Technology, Kakamega Campus
}

\begin{abstract}
The paper was done in the context of the Kenyan equity market which was represented at Nairobi Securities Exchange (NSE) for safaricom, a telecommunication firm. In this study excess returns over risk free rate was taken as dependent variable while market excess over risk free rate as independent variable. This study covers five and a half year period covering July 2008 through December 2013, the period over which Safaricom has existed as a listed company at the Nairobi Securities Exchange (NSE). Ordinary Least squares method was adopted in a linear asset pricing model to establish the statistical significance of the return premium over the NSE return. The findings indicate that Safaricom has a small return premium over and above the risk free rate of return. Secondly, the Safaricom return premiums are insignificant and that the main determinant of the equity market return premiums at the NSE is instead market characteristics. Imperatively, impressive financial performance of the technology companies as shown by their high profitability over the study period does not translate to a return premium that is significantly different from the returns of other companies quoted at the NSE.

Key words: Equity market, Market premium, Shareholders, Telecommunication,Firm Performance
\end{abstract}

\section{Background}

Pandey (2005), enhancing shareholders' wealth and profit making are among the major objectives of a firm. Shareholder's wealth is mainly influenced by growth in sales, improvement in profit margin, capital investment decisions and capital structure decisions (Azhagaiah and Priya, 2008). Firm performance in this case can be viewed as how well a firm enhances its shareholders' wealth and the capability of a firm to generate earnings from the capital invested by shareholders. It is therefore theoretically reasonable to expect good financial performance as reflected by profitability to affect equity securities market return premium. This is because shareholder wealth is maximized through the enhancement of the share prices of the companies targeted by the investors.

Share prices are determined at equity markets commonly called stock markets. Stock markets in the world individually and collectively play a critical role in the most nations economies. The market performs a wide range of economic and political functions while offering trading, investment, speculation, hedging, and arbitrage opportunities. In addition they serve as a mechanism for price discovery and information dissemination while providing vehicles for raising finances for companies. Stock markets are used to implement privatization programs, and they often play an important role in the development of emerging economies (Banz, 1981).

The determination of the market premium rate is very important for the capital market because it enables safer investment in a company and regulation of the market. This rate is the most important for the enterprise management and future investors. It is of importance for the management because it enables them to analyse the current state of the enterprise on the market and for future investors for safer investments of their capital.

The equity securities market in Kenya has grown from a humble background in the 1920s (NSE, 2014). In the 1920s when Kenya was a British colony, an informal way of dealing in shares and stocks commenced. In 1951, an Estate Agent Francis Drummond established the earliest professional Stock broking firm, and impressed upon the then finance minister of Kenya Sir Ernest Vasey the idea of creating a stock exchange in East Africa. Considering the proposal, which was given by Sir Ernest Vasey and Francis Drummond, the London Stock Exchange officials approved to recognise the creation of the Nairobi Stock Exchange as an overseas stock exchange in July, 1953. In 1954, the Nairobi Stock Exchange was comprised as a voluntary organization of stockbrokers enrolled under the Societies Act. The business of shares trading was restricted only 
to the resident European community but Africans and Asians were not permitted to deal in securities (NSE, 2014).

NSE (2014) further records that in 1980, The Kenyan Government understood the requirement of design and implemented policy transformation to promote the sustainability of economic growth with an efficient and steady financial system. In 1984, a Central Bank of Kenya study, "Development of Money and Capital Markets in Kenya" was known as a blueprint for structural reforms in the financial markets which helped the creation of a regulatory body 'The Capital Markets Authority' (CMA) in 1989. Notably, in 1994 the NSE 20-Share Index recorded an all-record high of 5030 points on Feb. 18, 1994. The NSE was rated by the International Finance Corporation (IFC) as the best performing market in the world with a return of $179 \%$ in dollar terms In December 1995; the entire Exchange Control Act was revoked. With the privatization of Kenya Airways in 1996, the largest share issue in the history of NSE, and the Kenya Airways Privatization team was rewarded the World Bank Award for Excellence for 1996.

Safaricom is one of the leading integrated communications companies in Africa with over 17 million subscribers. Safaricom provides a comprehensive range of services under one roof: mobile and fixed voice as well as data services on a variety of platforms. The company started as a department of Kenya Posts \& Telecommunications Corporation, the former monopoly operator, launched operations in 1993 based on an analogue ETACS network and was upgraded to GSM in 1996 (license awarded in 1999). Safaricom Limited was incorporated on 3 April 1997 under the Companies Act as a private limited liability company. It was converted into a public company with limited liability on 16 May 2002.

By virtue of the $60 \%$ shareholding held by the Government of Kenya (GoK), Safaricom was a state corporation within the meaning of the State Corporations Act (Chapter 446) Laws of Kenya, which defines a state corporation to include a company incorporated under the Companies Act which is owned or controlled by the Government or a state corporation. Until 20 December 2007, the GoK shares were held by Telkom Kenya Limited ("TKL"), which was a state corporation under the Act.

Following the offer and sale of $25 \%$ of the issued shares in Safaricom held by the GoK to the public in March 2008, the GoK ceased to have a controlling interest in Safaricom under the State Corporations Act and therefore the provisions of the State Corporations Act no longer applied to it.

\subsection{Statement of the Problem}

The telecommunications and technology companies have consistently declared comparatively huge accounting profits over the last five years yet it is not clear if these companies out-perform the market return performance of the stocks quoted at the NSE.

Safaricom has for instance posted the largest corporate profits in the East and Central Africa region over the past five years making it one of the top performing companies in the region. Paradoxically, however, an observation of the performance of the company's shares quoted at the NSE indicates that for most of the time, the price has either been below the IPO price of Sh.5 or the barely above it. This may point to a less than satisfactory performance that gives rise to the need for this study.

In a summary, the key dilemma necessitating this study is that whereas the telecommunications sector as represented by Safaricom has posted impressive accounting profits over last five years, it is not clear if the performance has been reflected in the equity security market performance of these companies. In addition, it is not clear how the annual financial performance of the companies is related to the annual equity market performance of the respective equity securities as traded at the NSE.

\subsection{General Objective}

To evaluate the relationship between the equity market return premium of the Telecommunications and Technology companies and profitability at the NSE using Safaricom as an empirical case over the five and a half year period of July 2008 to December 2013.

\subsubsection{Specific Objectives}

i. To establish the nature and relationship of the equity securities' market return premium in the highly profitable telecommunications sector in Kenya using Safaricom as an empirical case

ii. To evaluate the statistical significance of the Kenyan telecommunications firms' equity market return premium using Safaricom as an empirical case.

iii. To appraise the Kenyan telecommunications sector's annual equity securities' market return premium using Safaricom as an empirical case.

\subsection{Research Questions}

Using Safaricom as an empirical case of the Kenyan telecommunications companies, the study aims to find answers to the following research questions: 
i. What is the nature and magnitude of the equity securities' market return premium in the highly profitable telecommunications sector in Kenya?

ii. What is the statistical significance of the Kenyan telecommunications firms' equity market return premium?

iii. What is the nature of the trend in the annual equity securities' market return premium of the firms in the Kenyan telecommunications sector?

\subsection{Justification}

The study would help tell if the high accounting returns consistently reported by the public companies at the NSE, have been appropriately incorporated in the market prices as to constitute a market return premium of these companies over the rest of the quoted stocks. This is particularly necessary because investors have been complaining of the low trading prices of the Safaricom shares at the NSE since its listing in 2008 at a price of Sh.5.

The study is to be of policy and practical importance to a variety of stakeholders.

To investors and shareholders in the telecommunications sector particularly in the stocks issued by Safaricom Ltd, the findings of the study would help them assess the appropriateness of the market pricing of the accounting returns by the NSE. It would help them to shape their investment strategies based on financial performance and corporate profits.

To market regulators particularly the Capital Markets Authority (CMA), the findings of the study would help them assess the relationship between corporate financial performance and equity securities market performance. This can help them to develop and institute measures to enhance operational and informational efficiency in the Kenyan capital markets particularly of the NSE.

To the firms in the telecommunications sector; the findings would help them to appraise the acceptability of the pricing of the securities at the NSE. The trend in performance of the equity return premium is particularly helpful in this matter and it may help shape the need or otherwise of such strategies as the restructuring of securities at the NSE possibly through share consolidations or share splits.

\subsection{Scope of the Study}

The study uses Safaricom as a case study to establish if its impressive financial performance has translated into a commensurate equity market return premium over other companies quoted at the NSE. The study covers the five and a half year period of July 2008 through December 2013. The period is chosen because it corresponds to the time Safaricom Ltd has been a public company in Kenya. It is only over this period that information on the share price of the company is available. Safaricom is chosen as a case study because of its impressive profitability over the time frame this study is proposed. In addition it is the only telecommunications company quoted at the NSE as at the time of this study.

\subsection{Limitations of the Study}

In carrying out this study, the major limitation was that the research was based on the case method of evaluation. This was dictated by the fact that Safaricom was the only listed telecommunications company at the time of this study. It is however noted that the company is a representative of the companies in the sector since it enjoys over $60 \%$ of the market share of the sector as measured by a variety of parameters like the customer base, the usage of its related services like MPESA and asset base. With this, the findings are a representative of this sector.

\subsection{Introduction}

\section{Literature Review}

Telecommunications equity securities return premium examination tries to keenly analyze excess returns involved in each of the years under appraisal. The study was done in the context of equity securities markets also called stock markets. A stock market is an institution that deals in exchange of securities issued by publicly quoted companies and the government. The stock market is part of the broader market referred to as financial market (Pandey, 2005).

Due to technological companies market return premium in companies like Safaricom that provides a comprehensive range of services under one roof: mobile and fixed voice as well as data services on a variety of platforms. Here the capital market cost of capital is a discount rate, based on which discounted cash flow factor and residual value are determined. The cost of capital in literature is often found by the name of cost of capital or the opportunity cost of capital, which should provide a rate of return on capital that would be formed from an alternative investment capital. In order to achieve this, the cost of capital also includes market return premium to achieve the rate of return. The Weighted Average Cost of Capital (WACC) represents the average rate of return that a company must pay to shareholders and creditors. Most often, it is an adjusted discount rate, suitable for the risk of cash flows of companies. The cost of capital depends on the risk, and market return premium of cash 
flow businesses. In addition, most technological companies are financed by borrowing or lending of funds, whether from banks, individuals or other sources.

From main financial functions in determining marketing return premium of a company is financing. Therefore, we can say that the financing is compensation to the owners of capital, i.e. the cost of capital invested and engaged by technology means. The cost of capital is usually defined as the required rate of return on various forms of financing and it can be viewed from the standpoint of investors, customers and the value of the company. Each component of capital has its own individual capital cost expressed by a discount rate, which should be determined based on the market value of certain components of the capital, reflecting investors' requests for reimbursement, which means that they have to respond to investors' opportunities in the company. In this regard of marketing return premium, not only explicit but also implicit costs of capital need to be covered. The basic components of an enterprise capital structure include long-term debt, preferred stock, retained earnings and common shares. Every company has a different combination of these components that change over time (Kolcevic\&Hreljac, 2012).

When calculating the cost of capital, is necessary to cover the risk of achieving rates of return. According to their type, the risks are divided into (1) systematic risk and (2) non-systematic risk. The systematic risk includes factors arising from the economic and political environment, such as changes in exchange rates, fluctuations in raw material prices, inflation, tax reform, changes in the cost of salary levels and so on. These are general market risks that the company's management has no influence on and which investors cannot avoid by diversifying investments within the national economy. Therefore, the systematic risks are ignored in determining the cost of capital. Unsystematic risks are individual risks, they vary from company to company and they are conditioned by several factors: market position, competitiveness of own products in the market, level of dependence upon customers, suppliers and creditors, negative press reports, yielding, property and financial position. Unsystematic risks cannot be eliminated by changing technological companies' owners and management of companies. Their removal takes more time and they are conditioned by inventiveness and creativity of the company's management, among other things. In theory and practice, the cost of capital is determined by (Filipovic\&Rodic, 2010):

- Relative risk premium, or

- Capital Asset Pricing Model.

The relative risk premium, also called the method of masonry because it is based on the assumption that the discount rate and capitalisation rate are composed of a number of risk factors that can be identified and, when viewed together, a gives total return that an investor would expect from Safaricom Company. The market return premium rate is generally determined in two steps, and after their implementation, additional steps are possible, depending on the company being valued. The first step is to determine the rate of investment without risk on the valuation day.

Figure 1: Conceptual Framework

Independent variable Dependent

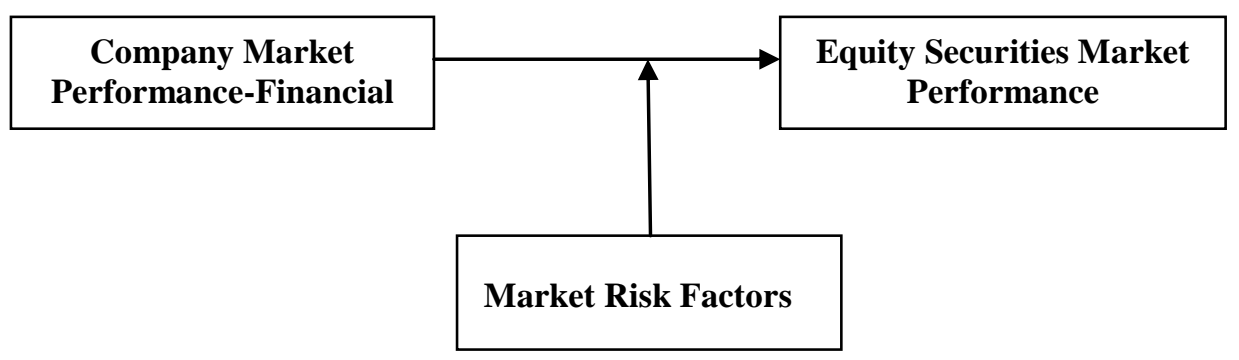

The figure 1 indicates that financial performance should be reflected in the security performance through the return premium. Whereas financial performance should affect the market performance, the effect is indirect and market risk factors act as moderating variables to influence the reflection of financial performance on market performance. The risk factors and the conditions at the NSE and the economy in general which affect the market performance of securities quoted at the NSE.

\subsection{Research Gap}

The key dilemma necessitating deriving from the review of literature is that there is lack of literature to appraise the relationship between the equity market performance of telecommunications companies in Kenya and their decidedly high profitability levels. The sector as represented by Safaricom has posted impressive accounting profits over last the five years, it is not clear if the performance has been reflected in the equity security market performance of these companies. In addition, it is not clear how the annual financial 
performance of the companies is related to the annual equity market performance of the respective equity securities as traded at the Kenyan equity markets.

\subsection{Research Design}

\section{Research Methodology}

The study used an empirical time series analysis of equity securities" excess returns over market returns over a 66 month period of July 2008 to December 2013 to evaluate the statistical significance of Jensen's alpha, the measure of market return premium. The decision to apply this design is supported by the recommendations of Mugenda and Mugenda (2003), according to which it is an appropriate fact finding tool for study since it facilitates collection of a large range of information.

\subsection{Target Population}

The population of study consists of the companies quoted at the Nairobi Securities Exchange which would be used in determining market returns as indicated by the NSE-20 share index. For the purposes of the study, this is compared with the market returns of the companies in the telecommunications sector of the NSE.

\subsection{Sample and Sampling Techniques}

Mugenda and Mugenda (2003), a sample is an element selected to represent the population while a sampling technique is a framework which the researcher uses to help in the selection of a sample. The study proposes to use convenience sampling to identify Safaricom as the case study given that its impressive financial performance is necessary to solve the problem stated for this study. Further, at the time of this study, Safaricom Ltd was the only company in the telecommunications sector quoted at the NSE.

\subsection{Data Collection Procedure}

The study used secondary data derived from the Nairobi Securities Exchange and at the Central Bank of Kenya as outlined below:

- Safaricom monthly market share prices were obtained from the NSE. These were used for computing the monthly returns of the company.

- 91-day monthly TB rates obtainable from the CBK. These are indicative of the risk free rate of return in the Kenyan financial markets and are used as a basis for computing market and company excess returns.

- NSE-20 monthly share index which were obtained from the NSE data. This monthly data is used for determination of the market returns of companies quoted at the NSE

\subsection{Data Processing and Analysis}

After data collection, the secondary data was organized, cleaned, edited, entered into computer and analyzed using the version of the statistical package for social sciences (SPSS version 17) the analysis was based on both descriptive and inferential statistics. The descriptive statistics focus particularly on the mean return premiums, standard deviation, and coefficient of variation of the Safaricom monthly equity returns. The inferential statistics involved testing the statistical significance of the telecommunications company's equity securities return premium using the t-statistic at the $95 \%$ confidence interval. The findings were then to be used to develop a report for examination in partial fulfillment of the requirements of the Masters Degree.

The study used the Ordinary Least Squares (OLS) Regression of the Safaricom excess returns on the overall NSE market excess returns to evaluate the statistical significance of the Safaricom market return premium. The model is specified as follows:

$R_{s}-R_{f}=\beta_{0}+\beta_{1}\left(R_{m}-R_{f}\right)+e$

Where:

$\mathrm{R}_{\mathrm{t}}$ represents the monthly market returns of the Safaricom Stock at the NSE

$\mathrm{R}_{\mathrm{f}}$ is the risk free rate of return derived from the 91-day treasury bill rate

$\beta_{0}=\alpha$ a constant whose statistical significance is to be evaluated to show if the Safaricom excess returns are consistently higher than the average NSE excess returns

$\beta_{1}$ is the rate of change in the market excess returns over the study period

$\mathrm{R}_{\mathrm{m}}$ is the overall monthly market return derived from the monthly NSE-20 share Index

$\mathrm{e}$ is the error term representing the other Safaricom excess return factors not captured in the linear equation.

\section{Dependent variable $=$ Excess returns over risk free rate \\ $=$ Return on the Safaricom Monthly Returns - Risk free Rate \\ Independent variable $=$ Market excess returns over risk free rate}




\section{$=$ Monthly Market Returns - Risk free Rate}

Stock return $=R_{s}=\frac{P_{s, t}-P_{s, t-1}}{P_{s, t-1}}=\operatorname{Ln} P_{s, t}-\operatorname{Ln} P_{s, t-1}$

Where:

$\mathrm{P}_{\mathrm{s}, \mathrm{t}}$ is the price of Safaricom share at the end of month $\mathrm{t}$

$\mathrm{P}_{\mathrm{s}, \mathrm{t}-1}$ is the price of Safaricom share at the beginning of month $t$

$\mathrm{Ln}$ is the natural logarithm

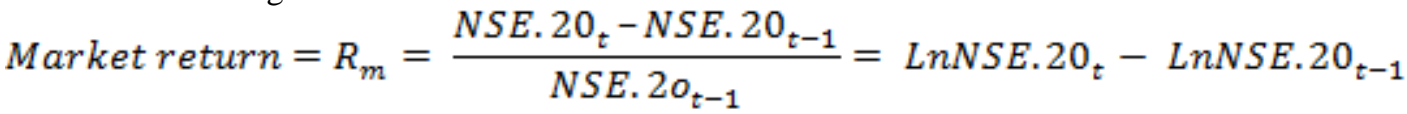

NSE. $20_{t}$ is the NSE-20 share index at the end of month $t$

$\mathrm{P}_{\mathrm{s}, \mathrm{t}-1}$ is the NSE-20 share index the beginning of month $t$

To evaluate the market return premium involved the use of descriptive statistics of the monthly returns over the 54 month period. The study checked:

- $\quad$ The mean of the excess returns

- The standard deviation of the excess returns

- $\quad$ The range of the excess returns

- The median of the excess returns

- The coefficient of variation of returns

The testing of the statistical significance of the Safaricom market return premium involved evaluation of the $\beta_{0}$ using the $\mathrm{t}$ - statistic at $95 \%$ confidence internal

\subsection{Introduction}

\section{Research Findings}

This chapter presents the findings and analysis of data. The study was done for the five and a half years covering August 2008 to December 2013 to evaluate the nature and type of the security return premium in the telecommunications industry given the high profitability levels. The data for regression analysis was drawn from the market data of Safaricom share prices, the 91-day treasury bill rate and the NSE-20 share index. The chapter captures the major findings and interpretations in line with the objectives of the study.

\subsection{Nature and Magnitude of Market Return Premium}

The Safaricom security premium was taken as the excess of Safaricom security market return over the risk free rate of return. The first objective aimed to evaluate the magnitude and trend of the return premium if any. Table 1 shows the descriptive statistics of the monthly Safaricom security return premium over the study period.

Table 1: Descriptive Statistics for Safaricom Equity Market Return Premium

\begin{tabular}{lr}
\hline Statistic $\quad \mathbf{R}_{\mathbf{s}} \mathbf{R}_{\mathbf{f}}$ & -0.00923 \\
\hline Mean & 0.010714 \\
Median & 0.23904 \\
Standard Deviation & 1.209947 \\
Range & -0.7013 \\
Minimum & 0.508649 \\
Maximum & 65 \\
Count & 0.059231 \\
\hline
\end{tabular}

Source: Data Analysis Results

The results show a mean return premium of $-0.923 \%$ over the study period at the $95 \%$ confidence interval. This implies that the return premium was on average a negative one. This is consistent with the low trading prices (near and below the IPO price of Sh.5 per share) of the Safaricom shares over most of the study time as indicated in appendix 4.

The complete picture can be evaluated by comparing the maximum, minimum and range of the return premiums. The highest return premium is $50.86 \%$ reflecting the initial jumps in prices following the IPO. From the average, this is subsequently wiped out to register a negative return premium of $-70.13 \%$. The negative average premium indicates that the negative returns have been more persistent than the positive returns. This provides an overall range of $120.995 \%$. Interestingly, the positive median of return premiums of $1.0714 \%$ indicates that the premium was mostly positive. The premiums have also been very volatile as indicated by the standard deviation of $\pm 23.904 \%$. 
The Safaricom position can be compared with the average return premium of all companies quoted at the NSE whose performance is reflected in the NSE-20 share index performance. This comparison is reflected in table 2. The comparison shows that from a descriptive level, there seems to be a Safaricom security market monthly return premium of an average of $1.028 \%$. This is because whereas the mean premiums of Safaricom are negative, the average premium of the market is a bigger negative value of $-1.9 \%$ per month. This seems to be confirmed by the apparent positive median of the Safaricom returns premium of $1.07 \%$ when compared to the average market position of $-1.256 \%$

In addition, the range of return premiums of the market is smaller than Safaricom's although the standard deviation is slightly lower. In a whole it can be confirmed that there exists a market return premium for the telecommunications equity securities as confirmed by the higher mean and median values for the Safaricom return premiums when compared with the average market return premiums

Table 2: Descriptive Statistics for NSE Equity Market Average Return Premium

\begin{tabular}{lrrr}
\hline Statistic & $\boldsymbol{R}_{\boldsymbol{m}}-\boldsymbol{R}_{f}$ & $\mathbf{R}_{\mathbf{s}}-\mathbf{R}_{\mathbf{f}}$ & Variance \\
\hline Mean & -0.01951 & -0.00923 & 0.01028 \\
Median & -0.01256 & 0.010714 & 0.023274 \\
Standard Deviation & 0.210753 & 0.23904 & 0.028287 \\
Range & 1.176839 & 1.209947 & 0.033108 \\
Minimum & -0.70124 & -0.7013 & -0.0001 \\
Maximum & 0.4756 & 0.508649 & 0.033049 \\
Count & 65 & 65 & - \\
Confidence Level (95.0\%) & 0.052222 & 0.059231 & - \\
\hline
\end{tabular}

Source: Data Analysis Results

The apparent premiums as implied by the foregoing descriptive statistics can be appraised further through inferential statistics

The second objective seeks to confirm and evaluate the statistical significance of the Safaricom equity market return premium. The model tested was specified as:

$R_{s}-R_{f}=\beta_{0}+\beta_{1}\left(R_{m}-R_{f}\right)+e$

The idea is to compare the linear relationship between the Safaricom market return premium and the overall market return premium. The premiums are computed as the excess returns of the security and the market over the risk free returns. As indicated in chapter3, the risk free returns are approximated as the returns on the 91-day TBs. The findings of the Study are shown in Table 3

Table 3:Summary Regression Output Results

\begin{tabular}{|c|c|c|c|c|c|c|c|c|}
\hline \multicolumn{2}{|c|}{ Regression Statistics } & & & & & & & \\
\hline Multiple $R$ & 0.920941 & & & & & & & \\
\hline$R$ Square & 0.848132 & & & & & & & \\
\hline Adj. $R$ Square & 0.845722 & & & & & & & \\
\hline$S E$ & 0.093891 & & & & & & & \\
\hline$N$ & 65 & & & & & & & \\
\hline \multicolumn{9}{|l|}{$A N O V A$} \\
\hline & $D f$ & $S S$ & $M S$ & $F$ & Sig. $F$ & & & \\
\hline Regression & 1 & 3.10160 & 3.10160 & 351.83456 & 0.00000 & & & \\
\hline Residual & 63 & 0.55538 & 0.00882 & & & & & \\
\hline \multirow[t]{2}{*}{ Total } & 64 & 3.65698 & & & & & & \\
\hline & $\boldsymbol{\beta}_{i}$ & Se & $t$-stat & P-value & $\begin{array}{c}\text { Lower } \\
95 \%\end{array}$ & $\begin{array}{c}\text { Upper } \\
95 \%\end{array}$ & $\begin{array}{c}\text { Lower } \\
95 \%\end{array}$ & $\begin{array}{c}\text { Upper } \\
95 \%\end{array}$ \\
\hline $\boldsymbol{\beta}_{0}$ & 0.01115 & 0.01170 & 0.95353 & 0.34397 & -0.01222 & 0.03453 & -0.01222 & 0.03453 \\
\hline$\beta_{1}$ & 1.04455 & 0.05569 & 18.75725 & 0.00000 & 0.93326 & 1.15583 & 0.93326 & 1.15583 \\
\hline
\end{tabular}

Source: Data Analysis Results

The findings indicate that the model is suitable for analysis given that the R-square value (coefficient of determination) of 0.848132 implies that $84.81 \%$ of the changes in the in the security return premium are explained by the model and that only $15.19 \%$ of the explanatory variables lie outside the model specification. $\beta_{0}$ denotes the excess returns of Safaricom equities over and over the market excess returns. The fact that the output t-statistic of 0.95353 is less than the critical value of 2.000 implies that the coefficient is statistically insignificant and that the $\beta_{0}$ value of 0.01115 is not significantly different from zero and is therefore statistically insignificant in the regression of Safaricom return premiums on market return premiums. This is confirmed by the relatively large p-value of 0.34397 . Accordingly, Safaricom's security return premiums are similar to the 
return premiums of the entire market on average. This implies that the Safaricom returns are typical of the average returns at the NSE on average, at least over the study period.

This seems to suggest that the high profits posted by the telecommunications industry in general and Safaricom in particular do not translate to higher market returns in the market. This seems to be consistent with the generally depressed Safaricom share prices over the study period.

The rate of change in market excess returns is evaluated by $\beta_{1}$. The $\beta_{1}$ is statistically estimated as 1.0445 . The corresponding t-statistic at $95 \%$ confidence interval is 18.75725 . The value is statically significant given that it is higher than the critical t-value of 2.000. The implication of this is that since $\beta_{1}$ is an indicator is market risk, the equity security returns at the NSE are mainly dependent of the market risk factors. Given that $\beta_{1}$ the indicator of returns unique to the features of Safaricom is insignificant, then the high profitability trends demonstrated by Safaricom are not translated into market return premium for the security investors. The security returns seem to be insensitive to the profitability of the telecommunications company and they seem to be an irrelevant factor as a predictor of equity returns and return premiums.

\subsection{The Trend of the Return Premium}

Given that Safaricom is a new listing at the NSE, it is important to evaluate the trends of the return premium to see if it is a function of the listing process and the trend in profits over time. To check this, the study uses graphs to establish trends in terms of market and security return premiums. For comprehensive examination, this is done both for monthly return premiums and well as the annual return premiums. Figure 2 shows the monthly trends of the Safaricom market return premium over the entire study period.

Fig 2

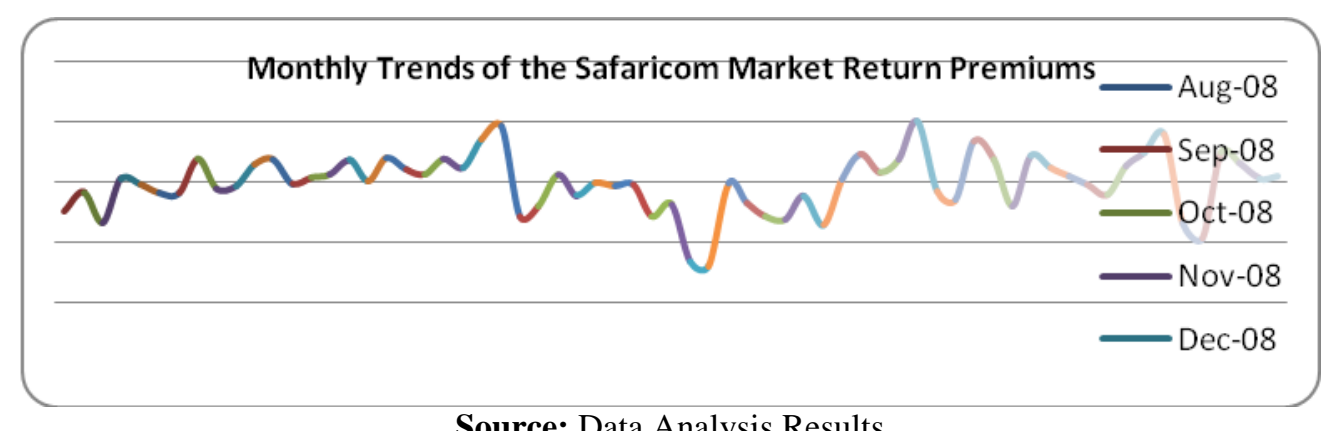

Source: Data Analysis Results

Observation from figure 2 shows that the Safaricom return premiums over the 66 month period represent roughly four cycles of growth, decline, growth and instability over four phases of the study period respectively. The first phase of growth is realized between August 2008 and June 2010. This represents the first phase post the IPO done in July 2008. The return premiums grew from roughly $-20 \%$ to $45 \%$. This could be attributed to the profit taking effect arising from the IPO. It is however slow possibly to the large volume of Safaricom shares issued in the primary market. The period also coincides in the phase where the capital markets experienced general uncertainty following the 2007-2008 post general elections violence in Kenya.

Between June 2010 and June 2011 there was a general decline in the equity return premium for the Safaricom equity security to a negative premium of approximately $70 \%$. This could be attributed to the uncertainty in profitability following the market price wars in the voice service, the main income contributor to players in the market. The decline cycle is relatively short however possibly after the market established the growth potential of the company despite the diminished income prospects from the voice services. The company had by this time established the data service and the mobile money transactions service (Mpesa) as growth segments of the industry and in which the company had made tremendous progress way ahead of the competitors.

Post June 2011 is the period over which the equity market returns premium for the Safaricom security has shown considerable volatility. The fluctuations have however mostly been in the positive territory which points towards a strong market performance of the security variability. The period in the later periods of the study particularly in the year 2013, the Safaricom share price increased considerably above the IPO price as indicated in appendix 4. It could mean that the volatility of the return premiums related the uncertainty surrounding the sustainability of the increased prices. This is more so because the price had before than almost always underperformed the IPO price.

For a more general picture of the trends discussed above, figure 3 shows the relationship between the average annual Safaricom market return premiums over the study period. 
Fig 3

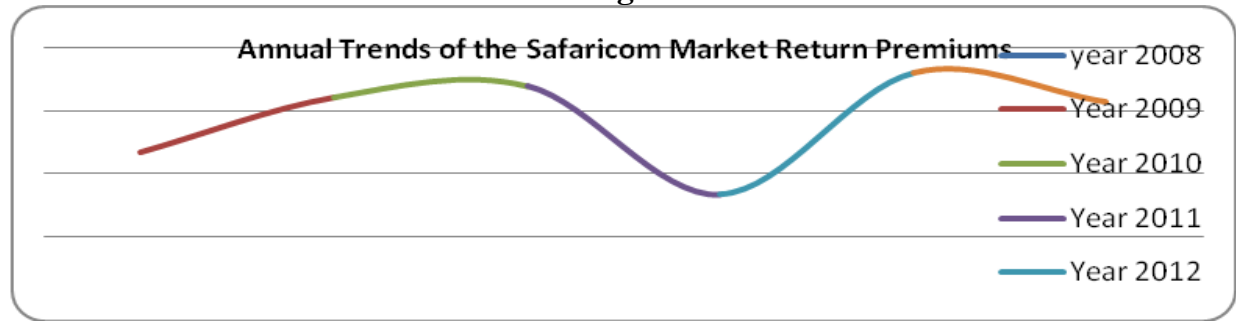

Source: Data Analysis Results

The general trend indicates that whereas the premiums have mostly been positive, the period between mid 2010 and mid 2012 showed a remarkable decline in the premiums. This coincides with the period when there were intense price wars in the telecommunications sector particularly for the voice services. Despite this, Safaricom exhibited growth in profitability.

The return premiums and the trends can conclusively be evaluated by comparing the overall NSE trends over the same period. The figures combine the individual return premiums for the Safaricom securities and the return premiums of the overall market as indicated by the performance of the NSE-20 share index. This is established in the trends shown in figures 4 and 5 respectively.

Figure 4:Monthly Trends of the Safaricom and NSE Market Return Premiums

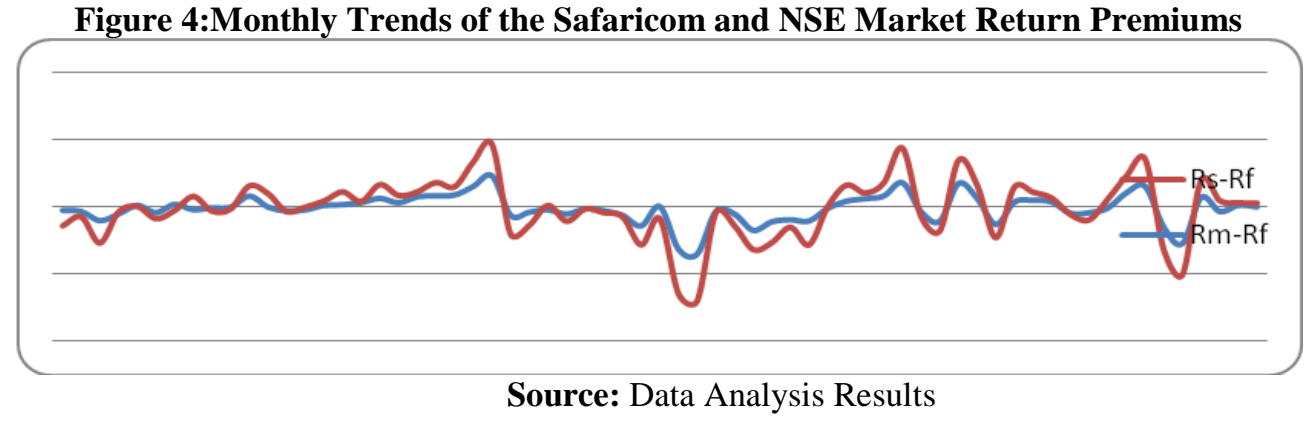

Figure 4 involves the superimposition of the Safaricom market return premiums $\left(\mathrm{R}_{\mathrm{s}}-\mathrm{R}_{\mathrm{f}}\right)$ on the overall NSE market return premiums $\left(\mathrm{R}_{\mathrm{m}}-\mathrm{R}_{\mathrm{f}}\right)$. The results are interesting given that Safaricom seems to follow the overall trends in the market. All the phases described as growth, decline, recovery and stability for Safaricom are also exhibited by the market. This seems to support the conclusion arrived at in research objective 2 that the main determinant of the equity return premiums at the NSE is the market risk characteristic as opposed to the unique characteristics of the company, like profitability for the case of Safaricom. Similarly, in support of the conclusion from objective 1, the market exhibits a wilder volatility of the market return premiums compared to the fluctuations shown by Safaricom security. This may imply that on average; the investments in Safaricom are less risky compared to the average risk level at the NSE market.

The results above are further evaluated on a more general basis by superimposing the annual return premiums of the Safaricom security $\left(R_{s}-R_{f}\right)$ on those of the market on average $\left(R_{m}-R_{f}\right)$. This is indicated in figure 5. The findings suggest as indicated in the foregoing paragraph that the premiums of the technology companies' securities (Safaricom in this case) and those of the entire market (as represented by Safaricom case) tend to move in synchrony.

Figure 5:Annual Trends of the Safaricom and the NSE Market Return Premiums

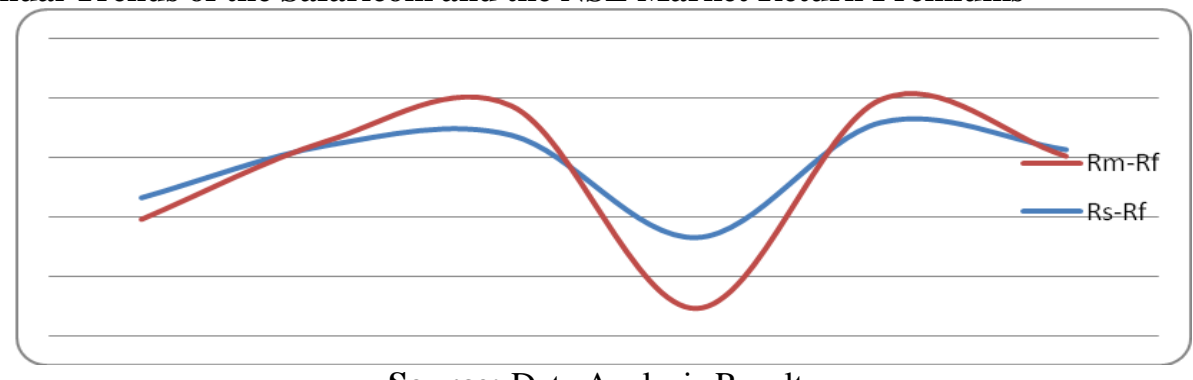

Source: Data Analysis Results 
When the findings for objective 1,2 and 3 respectively are considered together, the following observations become obvious:

Firstly, from the descriptive statistics, Safaricom seems to have a small return premium over and above the risk free rate of return. Secondly, the inferential statistics based on evaluating the statistical significance of the return premiums however show that at $95 \%$ confidence interval, the Safaricom return premiums are insignificant and that the main determinant of the equity market return premiums at the NSE is instead market characteristics and not individual company characteristics. Imperatively, impressive financial performance of the technology companies as shown by their high profitability over the study period does not translate to a return premium that is significant different from the returns of other companies quoted at the Nairobi Securities Exchange. Thirdly, this finding is confirmed by the trend results which show that even though NSE return premiums generally move together and positively correlated with those of the Safaricom securities. This is supported by the findings in table 4 that exhibits the Pearson's coefficient of correlation between the Safaricom equity market return premiums and those of the overall NSE.

Table 4: Correlation between Safaricom Return premiums and those of the Market

\begin{tabular}{lrr} 
Return Premium & $\boldsymbol{R}_{m}-\boldsymbol{R}_{f}$ & $\boldsymbol{R}_{s}-\boldsymbol{R}_{f}$ \\
\hline $\boldsymbol{R}_{m}-\boldsymbol{R}_{f}$ & $\boldsymbol{1}$ & \\
$\boldsymbol{R}_{s}-\boldsymbol{R}_{f}$ & 0.920941 & 1 \\
\hline
\end{tabular}

Source: Data Analysis Results

This indicates that there is a strong positive correlation between the Safaricom equity return premium and the overall market return premium as indicated by the coefficient of correlation of 0.92 . This supports the findings for objective

\subsection{Conclusion}

\section{Conclusion And Recommendations}

Results from the study show that even though there is a small return premium over and above the risk free rate of return, the excess returns are not statistically significant. In reality, the main determinant of security return premium at the NSE is instead market risk characteristics and not individual company characteristics. The market risk characteristics are defined by the market risk premium whose beta was determined to be statistically significant in this study. Imperatively, impressive financial performance of the technology companies as shown by their high profitability over the study period does not translate to a return premium that is significantly different from the returns of other companies quoted at the Nairobi Securities Exchange. In essence, the equity market return premiums of the telecommunications industry are positively correlated with the overall market risk characteristics and that the profitability of the telecommunications sector have little, if any, effect on the security return premiums.

This finding could be attributed to a number of factors. Firstly, the Kenyan equity market represented by the NSE is relatively small and this does not provide enough opportunities to compare investment characteristics beyond the risk perspectives.

Secondly, out of all the telecommunications firms in Kenya, only Safaricom ltd is quoted at the NSE. This greatly limits the decision opportunities available to the investing public. It may be that investors are left with little choice but to invest in the company because of this monopoly characteristic and its dominant market position. If this is true, the profitability of the company plays a little role on the return premium given that the driving force in the investment is hardly the financial performance of the company.

In addition, Safaricom offered a large number of shares to the investing public (10 billion) at its IPO. With this wide shareholding, the market price has largely been unresponsive to the improvements in the financial performance of the company. With a different capital structure, the results could possibly have been different. This is because, if most of the investors are long term buy and hold investors, the participants in the secondary market would have an insignificant influence on the market share prices.

\subsection{Recommendations}

It is recommended that further exploration of the returns premium could be undertaken using a different regression model possibly one that takes long term time series information into account. This may help reveal information not capable of discovery using the ordinary least square model adopted in this study.

Lastly, the coefficient of determination from the regression model indicated that only $86 \%$ of the changes in the dependent variables (Security return premium) was explained by the model. Another study could be undertaken to evaluate the other factors that determine market return premium and to determine the nature and characteristics of the market risk factors in the Kenyan capital markets. 


\section{References}

[1] Ariel, R. A. (1990), "High Stock Returns Before Holidays: Existence and Evidence on Possible Causes," Journal of Finance, 45(5), December, 1611-1626.

[2] Azhagaiah, R. and Priya, S. (2008). The impact of dividend policy on shareholders' wealth. International Research Journal of Finance and Economics, 20, $180-187$.

[3] Banz, R. (1981). The relationship between return and market value of common stock. Journal of Financial Economics9, 3-18.

[4] Davis, J. (2006). What contributes to shareholder value? Sustainable Development Manager. Duke and Rice Universities.

[5] DeBondt, Werner F. M. and Richard Thaler (1995), “Does the Stock Market Overreact?” Journal of Finance, 40, $793-805$.

[6] Fama, E.F. (1970). Efficient Capital Markets: A Review of Theory and Empirical Work. Journal of Finance, 25, 383-417.

[7] Fama, E. and Schwert, G.W. (1977). Asset Returns and Inflation. Journal of Financial Economics, 5, 55-69.

[8] Jecheche, P. (2009). An empirical investigation of the capital asset pricing model: studying stocks on the Zimbabwe Stock Exchange.Journal of Finance and Accountancy 2, 23-40

[9] Kolačevic, S., Hreljac, B. (2012). Evaluation of Enterprise: Business Consulting, Zagreb

[10] Mugenda, O. and Mugenda, A. (2003). Research Methods. Quantitative and Qualitative Approaches. African Centre for Technology Studies (ACTS) Nairobi.

[11] Pandey, M. I. (2005). Financial Management, 9th Edition, Vikas Publishing House, India

[12] Rodic, J., \&Filipovic, M. (2010). Procenavrednostipreduzeca.Belgrade: Asimex. (in Serbian)

[13] Turner, J. A. "Improving the Quality of Information Systems Research" in Proceedings of the First International Conference on Information Systems,Philadelphia, Pennsylvania, December 8-10, 1980, pp. 91-97

[14] Van Horn, R. L. "Empirical Studies of Management Information Systems," Database (5:2, 3, \&4) winter 1973, pp. 172-180 